\title{
Reexamining Secularism
}

\section{The Ayodhya Dispute and the Equal Treatment of Religions}

\author{
Geetanjali Srikantan \\ Assistant Professor of Global Legal History, Tilburg Law School \\ G.Srikantan@uvt.nl
}

\begin{abstract}
It is widely recognized that the secular Indian state unlike its Western counterpart does not follow the strict separation of religion and state, opting to intervene in the domain of religion by treating religions equally. This article examines how the concept of equal treatment of religions is applied in the legal domain by an intellectual history of the Ayodhya litigation and argues that the courts cannot treat religions equally due to the incompatible nature of the claims made by the parties i.e. the history of religion claim of the Hindus vis-a-vis the property rights claim of the Muslims. Departing significantly from the current consensus about the litigation being characterized by defective legal interpretation and political influences, it further argues that the real legal challenge in resolving this dispute is addressing the theological frameworks within modern property law which are dependent on a set of normative inferences embedded in colonial discourse.
\end{abstract}

* Acknowledgments: Versions of this paper have been presented at the symposium on "Unexpected Sources of Law" held at the David Berg Foundation Institute for Law and History, Tel Aviv University, and the Conference on Religion and Equality held at Bar Ilan University. For inputs on this paper I am indebted to Ron Harris, David Schorr, Assaf Likhovski, Roy Kreitner, Lena Salaymeh, Levi Cooper and Ayelet Libson. I would also like to thank Amos Israel, Haim Shapira and all the participants at the Conference on Religion and Equality for their various comments on this paper. This article has been made possible with the funding from the following institutions, the Israeli Council of Higher Education, the Buchmann Faculty of Law, the David Berg Foundation Institute for Law and History, and the Cegla Center for Interdisciplinary Research of the Law.

Note: Spellings used in the article are according to the records consulted.

(C) GEETANJALI SRIKANTAN, 2017 | DOI 10.1163/22124810-00502002

This is an open access article distributed under the terms of the prevailing CC-BY-NC license at the time of publication. 


\section{Keywords}

secularism - wakf - Ayodhya - Hindu endowment

Here is a small piece of land (1500 square yards) where angels fear to tread. It is full of innumerable land mines. We are required to clear it... Once angels were made to bow before Man. Sometimes he has to justify the said honour. This is one of those occasions. We have succeeded or failed? No one can be a judge in his own cause.

September 30, 2010. Justice S.U. Khan ${ }^{1}$

It is most unfortunate that a masjid should have been built on land specially held sacred by the Hindus, but as that event occurred 356 years ago it is too late now to remedy the grievance. All that can be done is to maintain the parties in status quo.

District Justice Chamier ${ }^{2}$

The transformation of the conflict surrounding 1,500 square yards in the small town of Ayodhya, in colonial North India, from a local dispute involving the ruling Shia king of Awadh, his Hindu and Sunni Muslim subjects, and the British colonial regime ${ }^{3}$ into one of the best known examples of inter-religious tension in modern India can be traced in the one hundred years that have lapsed between the pronouncements of the two judges. How did a colonial judge's assumption that a mosque was built on land held sacred by the Hindus turn into a complex property dispute about adverse possession, title, and customary usage replete with historical and theological claims? What were the burdens on the post-colonial judge to decide such a case in accordance with the constitutional guarantees of secularism and religious freedom in India?

1 Gopal Singh Visharad v Zahoor Ahmed ,o.s. No.1 of 1989 (Regular Suit No.2 of 1950) Nirmohi Akhara v. Priya Dutta Ram, o.s. No.3 of 1989 (Regular Suit No.26 of 1959), Sunni Central Board of Waqfs, U.P. and others v. Gopal Singh Visharad (since deceased) and others 0.s No.4 of 1989, (Regular Suit No.12 of 1961), Bhagwan Sri Ram Lala Virajman and others v. Rajendra Singh and others O.s No.5 of 1989 (Regular Suit No.236 of 1989) (hereinafter, the Ayodhya judgment); at http://elegalix.allahabadhighcourt.in/elegalix/DisplayAyodhyaBenchLandingPage.do.

2 Civil Appeal No.27 of 1886 in Infra n. 39.

3 See Juan Cole's extensive study of the Awadh state in Roots of North Indian Shitism in Iran and Iraq: Religion and State in Awadh, 1722-1859 (University of California Press, 1988), particularly the chapter on communal relations. 
These are questions that have not been satisfactorily answered in the Ayodhya dispute, a litigation on whether the birthplace of the Hindu deity Ram is on the site of a mosque known as the Babri Masjid, allegedly built by the $\mathrm{Mu}$ ghal Emperor Babur four centuries ago. According to Hindu devotees, Babur allegedly demolished a temple dedicated to Ram on the spot of Ram's birthplace and built a mosque. This dispute, which originated in 1885 , has continued well into the 21sth century, leading to widespread violence and conflict, and the destruction of the mosque on December 6, 1992 by Hindu political groups, which then demanded the rebuilding of the temple on the site of the demolished mosque. These demands were taken up by the Allahabad High Court, which had jurisdiction in the federal region in the Ayodhya case. In a controversial ruling, on September 30, 2010, the High Court pronounced the sanctum sanctorum or the innermost shrine of the mosque to be the birthplace of the deity Ram. Among other decisions on ownership of land, the High Court also awarded ownership of the site to representatives of the Hindu group, Vishwa Hindu Parishad.

This decision evoked sharp criticism from a wide range of commentators in the Indian press. An editorial in a leading Indian magazine commented that the judgement showed "insufficient understanding of the secular tenets of the Constitution." ${ }^{4}$ Yet another editorial criticized the court for not restoring faith in secularism and justice to minorities. ${ }^{5}$ Legal scholars, Rajeev Dhawan ${ }^{6}$ and A.G. Noorani, ${ }^{7}$ pointed out various legal deficiencies in the judgment, and historian Romila Thapar maintained that it had "annulled respect for history, seeking to replace it with religious faith." ${ }^{8}$ The only voice to depart from this consensus was that of the political scientist, Pratap Bhanu Mehta, who declared that it was a judgment that befitted India, and was not an implausible way of strengthening secularism. ${ }^{9}$

As these reactions show, the resolution to the Ayodhya dispute has been framed mainly as a question of the ability of the Indian state to uphold its

4 V. Venkatesan, "Weak legal basis", 27 (21) Frontline (2010). It can be accessed at http://www .frontline.in/static/html/fl2721/stories/20101022272101700.htm.

5 Editorial "The Undermining of Justice" 45(41) The Economic and Political Weekly (2010), 7.

6 V.Venkatesan, "Seriously flawed" (Interview with Rajeev Dhawan), 27(21) Frontline (2010). It can be accessed at http://www.frontline.in/static/html/fl2721/stories/20101022272102000. htm.

7 A.G. Noorani, "Muslims wronged", 27(21) Frontline (2010). It can be accessed at http:// www.frontline.in/static/html/fl2721/stories/2010102227211250o.htm.

8 Romila Thapar, “The verdict on Ayodhya: A historian's perspective”, The Hindu, October 2, 2010.

Pratap Bhanu Mehta, “The leap and the faith”, The Indian Express, October 1, 2010. 
constitutional commitment to secularism. ${ }^{10}$ Is the Indian state neutral and secular, and can it treat religions equally? How does one enforce the principle of secularism in India? Are religious minorities protected under the Indian Constitution?

The answers to these questions may appear to be straightforward. The right to the freedom of religion is a fundamental right under the Indian Constitution, specifically outlined in Articles 25 to $28 .^{11}$ There are allied rights that provide equality before the law, such as Article 14, and guarantee freedom from discrimination on the basis of religion, such as Article 15 .

The protection of religious freedom offered by the Indian state appears to conform to the models prescribed in international law, such as the Universal Declaration of Human Rights, 1948, the International Covenant on Civil and Political Rights, 1966, and the United Nations Declaration on the Elimination of All Forms of Intolerance and of Discrimination Based on Religion or Belief, $1981 .{ }^{12}$

These forms of legal protection, however, do not clarify the true relationship between state and religion in India. This topic was the subject of much debate and discussion in the Constituent Assembly, where the idea of the strict separation between state and religion gave way to the concept of equal treatment of religions, ${ }^{13}$ allowing the Indian state to interfere in religion in the guise of treating religions equally. Constitutional provisions have empowered the state to abolish social practices, including untouchability, and to intervene in

10 Only a few scholars have attempted to understand the Ayodhya dispute outside the framework of secularism. Using Indian philosophy, Ramachandra Gandhi shows how the exclusivity of the claims of Hindu political groups privileges the birthplace of Ram but ignores another spot revered as Sita's kitchen (Sita is Rama's wife) within the disputed site. In doing so, the claims of these Hindu groups negate Indian spirituality. See Ramachandra Gandhi, Sita's Kitchen: A Testimony of Faith and Inquiry (State University of New York Press, 1992).

11 These include the freedom of religion or conscience, more specifically, the right to profess, practice, and propagate religion, the right to form educational institutions for religious or charitable purposes, and a prohibition of religious instruction in state-funded institutions.

12 For a discussion on how relations between state and religion can be schematized in terms of various approaches, see Yuval Jobani and Nahshon Perez, "Women of the Wall: A Normative Analysis of the Place of Religion in the Public Sphere", 3(3) Oxford Journal of Law and Religion (2014), 484-505. The Indian state may fall within the evenhandedness approach, i.e., equal treatment although it has often been accused of taking the dominant culture approach, i.e., favouring the culture of the majority in making decisions that involve religion.

13 Shefali Jha, "Secularism in the Constituent Assembly Debates, 1946-1950", 37(30) Economic and Political Weekly (2002), 3175-3180. 
the management of Hindu religious institutions. ${ }^{14}$ Religious communities are permitted to have their own systems of marriage and inheritance, known as personal laws, which are subject to judicial control. Separate legal frameworks, in the form of wakfs and Hindu endowments, govern Muslim and Hindu places of worship..$^{15}$ The Indian state engaged in a large-scale reform of Hindu law in the 195 s $^{16}$ and has continued to make amendments to the personal laws of religious communities. Recent amendments have included amending the Christian personal law relating to divorce through the Indian Divorce (Amendment) Act of 2001, ${ }^{17}$ and Hindu succession law through the Hindu Succession (Amendment) Act of 2005 .

This form of secularism has been understood by many intellectuals as viable and necessary, ${ }^{18}$ but has drawn sharp criticism from various Hindu political groups, including the Bharatiya Janata Party (BJP), as "pseudo-secularism."19 These groups have alleged that constitutional provisions on secularism are being misused to provide concessions to religious minorities, an example being the lack of initiative by the Indian state in reforming Muslim personal law while reforming Hindu law. Therefore, there is no equal treatment of religions. These stances have affected the Ayodhya litigation, the BJP, and other Hindu

14 Found in Articles 17 and 25 of the Constitution.

15 Christian churches are generally governed according to the model of the English trust. Separate legislation governs places of worship, known as gurudwaras, belonging to the Sikh community.

16 See Duncan Derrett, "The Codification of Hindu Law" in Religion, Law and the State in India (Oxford University Press, 1968), 321-351, for an account of these reforms.

17 For a critical analysis of the amendments to Christian personal law and the debates behind them, see two articles by Flavia Agnes titled "Minority Identity and Gender Concerns", 36(42) Economic and Political Weekly (2001), 3973-3976, and "Church, State and Secular Spaces", 35 (33) Economic and Political Weekly (2000), 2901-2904.

18 Rajeev Bhargava, "What is Secularism For" and Charles Taylor "Modes of Secularism" in Rajeev Bhargava and Partha Chatterjee (eds.), Secularism and Its Critics (Oxford University Press 1998), 486-542. Gary Jacobsohn, in The Wheel of Law: India's Secularism in Comparative Constitutional Context (Princeton University Press 2003), argues that the Indian state practices ameliorative secularism, which involves an agenda of dismantling social hierarchy. An exception to this consensus about the affirmative effects of secularism is Ashis Nandy, who argues that secularism in India is unable to draw upon non-institutionalized forms of pluralism shown by how different religious communities have lived together in Indiain the past. See Nandy, "The twilight of certitudes: Secularism, Hindu nationalism and other masks of deculturation", 1(3) Postcolonial Studies (1998), 283-298.

19 This term came into popular usage in the 1980 s, when the BJP sought to assert its presence nationally; it was first used in 1969 by the BJP leader, Atal Behari Vajpayee. See Christophe Jafferelot, The Hindu Nationalist Movement and Indian Politics: 1925 to the 199o's (Penguin, 1999), 376. 
political parties, which view the movement to establish a temple in Ayodhya as evidence that their ideology, known as Hindutva, ${ }^{20}$ is an effective alternative to "pseudo-secularism." Others, however, have criticized the judicial interventions in this dispute as a failure of secularism. ${ }^{21}$

The present article explains how the Indian state has upheld secularism as a legal and constitutional commitment through the principle of the equal treatment of religions in the course of the Ayodhya dispute. To do so, we must confront the issue of how religion is understood by the law, how the courts define religion, and the conceptual frameworks and compulsions that they face in making such a decision. Finally, we answer the question of how these considerations have affected the Ayodhya dispute.

The Supreme Court has displayed considerable ambiguity regarding the definition of religion. In S.P. Mittal v. Union of India, ${ }^{22}$ the Court noted that religion was incapable of precise judicial definition because there are problems with the concept itself, "some religions being more easily identifiable as religious and some are easily not identifiable as religious." This pronouncement was made despite efforts to develop standards for the definition of religion in The Commissioner, Hindu Religious Endowments, Madras v. Sri Lakshimindra Thirtha Swamiar of Sri Shirur Mutt, ${ }^{23}$ where it was held that the courts must consult the doctrines of a religion defined in its "essential practices" in order to determine whether any set of practices were religious. ${ }^{24}$

Such difficulties in the definition of religion by the law are increasingly noticeable also in other jurisdictions and also in international law. ${ }^{25}$ However,the

20 Hindutva is a form of Hindu nationalism promoted by the BJP, outlined in the works of its leaders, such as Savarkar and Gowalkar. See V.D Savarkar, Hindutva: What is a Hindu (Veer Savarkar Prakashan, 1969), and M.S. Gowalkar, We or Our Nationhood Defined (Kale Publications, 1947).

21 Nivedita Menon, "The Ayodhya Judgment: What Next?" 66(31) Economic and Political Weekly (2011), 81-89; Ratna Kapur, "A Leap of Faith: The Construction of Hindu Majoritarianism through Secular Law", South Atlantic Quarterly (2014), 109-128; Rajeev Dhawan, "The Ayodhya Judgement: Encoding Secularism in the Law", 29 (48) Economic and Political Weekly (1994), 3034-3040.

$22 \quad 1983$ SCC (1) 51.

23 AIR 1954 SC 282.

24 This test, however, proved impossible to implement. The courts handed down contradictory decisions, prompting criticism that with the application of the test the courts have been serving a "reformist agenda," leading to an "unmanageable jurisprudence of religious freedoms." See Rajeev Dhawan, "Religious Freedom in India", 35(1) The American Journal of Comparative Law (1987), 209-254.

25 For difficulties in defining religion in international law, see T. Jeremy Gunn, "The Complexity of Religion and the Definition of "Religion"' under International Law", 16 Harvard Human Rights Journal (2003), 189-215. For questions regarding about the limits of the 
unintelligibility of religion as a legal phenomenon in India leads to further difficulties in determining the relationship between the state and religion. For instance, how does the Indian state decide the domain of its "interference," i.e, how does it demarcate activities as religious or secular when it comes to benefits, policies and exemptions in the areas of taxation, education, and charity. Such demarcation becomes crucial because both institutions and individuals stand to benefit from such policies.

Ronojoy Sen, in an exhaustive treatment of the Supreme Court decisions on religion, argues that the essential practices test has evolved over the several decades it has been in use, and that this test has been influenced by the views and attitudes of the judges themselves. ${ }^{26}$ Initially, under the influence of Justice Gajendragadkar, the court attempted an agenda of social reform, seeking to eliminate "unessential" practices that they deemed superstitious or irrational, and rationalizing religion by putting the state in charge of religious endowments. This attitude underwent a transformation in the 199os owing to Justice Ramaswamy, who provided a philosophical basis for the test, emphasizing dharma or good consciousness as the core of religion, thus placing the emphasis on religious experience.

Marc Galanter argues that the jurisprudence of the Indian Supreme Court on the definition of Hinduism reflects judicial preoccupation with the reform of Hinduism into an entity that can be easily regulated. ${ }^{27}$ Judges may feel an obligation to contribute to a sense of nationhood by providing a unified description of Hinduism. According to Galanter, this raises the wider question of whether judges are legitimately bound by the Constitution to actively engage in an exercise of reinterpreting Hinduism.

Both Galanter and Sen raise valid questions about the role of judges in creating doctrine. This does not answer, however, the question about the theoretical framework that courts use in understanding religion. Sen's argument that the Supreme Court rulings are a product of a discourse embedded in classical Hinduism, which originated in the 19th century and provided the basis for the argument that social reform was required, does not address the conceptual

public sphere in the context of the neutral secular state in Germany, see Karl-Heinz Ladeur and Ino Augsberg, "The Myth of the Neutral State: The relationship between state and religion in the face of new challenges", 8(2) German Law Journal (2007), 143-152. For an appraisal of the constraints of American courts in defining religion, see Winnifred Fallers Sullivan, The Impossibility of Religious Freedom (Princeton University Press, 2005).

26 Ronojoy Sen, Articles of Faith: Religion, Secularism and the Indian Supreme Court (Oxford University Press, 2010).

27 Marc Galanter "Hinduism, Secularism and the Indian Judiciary" in Law and Society in Modern India (Oxford University Press, 1989), 237-258. 
framework within which this discourse developed. ${ }^{28}$ Such a framework is provided by Ratna Kapur, who argues that the inability of the Supreme Court to interpret secularism in the right manner lies in its understanding of Hinduism. Influenced by colonialism, the Court has privileged Ram as supreme deity and Hinduism as a scripture-based religion akin to the Abrahamic religions, all of which have foundational scriptures and centralized doctrinal schools of interpretation. ${ }^{29}$ This "modern and singular construction" of Hinduism has converged with the idea of Hinduism propounded by Hindu political parties, such as the BJP, and other entities that share its agenda, such as the Rashtriya Swayamsevak Sangh (RSs) and the Vishwa Hindu Parishad (VHP). ${ }^{30}$

This answer goes beyond Galanter and Sen in outlining the conceptual framework that lies at the basis of the Court's understanding of Hinduism, which both judges and lawyers must grapple with. It also raises the important question of why does such a "construction" of Hinduism allow the Hindu political parties to deploy the discourse of secularism so effectively in a judicial context. Answering this question requires engagement with the concept of religion itself. Scholars of religious studies ${ }^{31}$ have shown that religion as a concept is studied through the Christian theological framework, and that one needs to be critical of the domain of the secular. A more specific perspective on the domain of the secular is provided by Gil Anidjar, ${ }^{32}$ who argues that Christianity is a secularized religion, having disenchanted itself into private and public, politics and economics, and the religious and secular, and viewing other communities and traditions as "religion," although it was the only

28 See Sen, supra n. 26, 1.

29 See Kapur, supra n. 21, 115. Kapur's analysis is based not only on the Ayodhya litigation but also on the various judgments on Hindutva that involved charges of hate speech against politicians from Hindu political parties, and their defense that these were legitimate appeals to Hindutva. In the main judgment, Dr. Ramesh Yeshwant Prabhoo v. Shri Prabhakar Kashinath Kunte and Ors. 1996 SCC (1) 130, the Supreme Court held that Hindutva was a way of life leading to the interpretation that the statements pertaining to hate speech were secular. According to Kapur, such an interpretation, which did not distinguish between Hinduism and Hindutva, failed to see how these political parties were appropriating secularism.

30 See Kapur, supra n. 21, 121-122.

31 See Talal Asad, Genealogies of Religion:Discipline and Reasons of Power in Christianity and Islam (The John Hopkins University Press, 1993); Timothy Fitzgerald, The Ideology of Religious Studies (Oxford University Press, 200o); S.N. Balagangadhara, The Heathen in His Blindness: Asia, the West and the Dynamic of Religion (Brill Publications, 1994); Richard King, Orientalism and Religion: Post Colonial Theory and the Mystic East (Routledge, 1999). Gil Anidjar, "Secularism", 33 Critical Inquiry (2006), 59-6o. 
example of religion..$^{33}$ Anidjar's findings on the linkages between modern social categories and religion along withthe conclusions reached by other scholars should make us rethink our understanding of secular law and compel us to re-examine the various legal concepts in operation in the Ayodhya dispute, such as the wakf and the endowment, which are used to make Muslim and Hindu claims to property. In the course of such re-examination, we must examine whether these concepts, along with modern property law, are free from their colonial origins, which reflect British colonial perceptions of religion.

I use the analysis of the Ayodhya dispute, particularly the judgment of September 30, 2010, to shed light on the inability of the Indian state to apply the doctrine of secularism in a neutral manner. I argue that this legal dispute brings to light the paradoxes and difficulties in the inability of Indian secularism to treat religions equally. I show that the problem that arises is the incompatible nature of the claims, the Hindu claim being based on the history of religion, as opposed to the Muslim claim, which is juridical in nature and based on title to property. Such claims reveal that the legal challenge in demarcating the religious and the secular is not a matter of boundaries, but has to do with addressing the theological frameworks of property law, which are dependent on a set of normative inferences embedded in colonial discourse.

The objective of the present article is not to analyze the legal argumentation favoring either side, or how political parties and Hindu groups, such as the Vishwa Hindu Parishad, have tried to influence the outcome of the litigation. Instead, I seek to review the intellectual history of the dispute. I begin by tracing the shifts in the legal history of the Ayodhya dispute. By the narration of such a legal history I seek to delineate the broader conceptual contours of the dispute and the conditions that make possible to e allow facts and represent them in the realm of law. ${ }^{34}$ Next, I focus on the September 30, 2010 judgment, with particular emphasis on the role of colonial writings, such as gazetteers and travel accounts, showing the background against which competing claims of Muslim property rights and Hindu historical-theological rights unfold. I show that the courts are drawn into a discourse on sovereignty, seen as control and authority over territory, which brings into operation secular property law.

33 See also Jakob De Roover, Sarah Claerhout, and S.N. Balagangadhara, "Liberal Political Theory and the Cultural Migration of Ideas", 39(5) Political Theory (2011), 571-599, for an understanding of the process by which Christian ideas become secularized.

34 I am inspired by Reinhart Koselleck, The Practice of Conceptual History: Timing History, Spacing Concepts, (Todd Samuel Presler, trans.) (Stanford University Press, 2002) and Michel Foucault, The Archaeology of Knowledge: The Discourse on Language (Sheridan Smith, trans.) (Pantheon Books, 1972). 
The property law concepts used to determine religious rights are influenced by a Christian theological framework based on the cognitive background of the British colonizers. The operation of these concepts is brought into being by colonial discourse. I conclude by arguing that we need to rethink property law in the context of its ability to regulate religion, and that the challenge lies in unraveling colonial discourse. ${ }^{35}$

\subsection{Colonial Beginnings}

An exploration of the legal problems around the disputed site of Ayodhya involves engagement with the law governing places of worship. Section 2 (c) of The Places of Worship Act, $1991,{ }^{36}$ states that the place of worship "means a temple, mosque, gurudwara, church, monastery or any other place of public religious worship of any religious denomination or any section thereof, by whatever name called." As noted, the legal categories of the wakf and the Hindu endowment govern temples and mosques, respectively. A wakf is defined under Section 2 ( r ) of the Wakfs Act, 1995 (an enactment by the federal government of India), as the permanent dedication of a property recognized by the Muslim law as pious, religious, or charitable, and which requires certain elements, such as a mutavalli or manager of the property. Each federal state has its own Wakf Board, with separate rules of operation. A Hindu endowment is defined in a similar manner, as being dedicated for purposes that are religious or charitable within the framework of religious and charitable endowment enactments that are separate for each federal state.

The ambit of the place of worship can include other entities, such as dargahs (saints' tombs), being classified under wakfs or vrindavanas (sacred groves) under Hindu endowments. ${ }^{37}$ Until the beginning of the 20 th century, however, such legal entities did not exist, and instances of temples and mosques were

35 This article does not examine the various criminal cases filed in connection with the dispute because these are merely an outcome of the property dispute.

36 This enactment, brought into force to negate any further claims on places of worship by various communities, provides that no alteration shall be made to any place of worship after August 15, 1947. But it was ineffective in preventing the demolition of the mosque at Ayodhya because it did not apply to that site.

37 Section $2(\mathrm{k})$ (i) of the Wakf Act, 1995, refers to a person interested in a wakf as being entitled to worship at dargahs, among other places. For vrindavana being a place of worship, see Section 2(24) of the Karnataka Hindu Religious and Charitable Endowments Act, 1997. 
defined by their function, and not an abstract purpose. ${ }^{38}$ Legislation conceptualizing these categories was enacted only in the early zoth century, showing the links between post-colonial legislation and colonial legal culture.

It is therefore important to examine the Ayodhya dispute from the point of view of its colonial origins. From such a perspective, it is unsurprising that many commentators trace this dispute to events in the colonial period, which saw increased conflict between religious communities amid British efforts to annex the kingdom of Awadh (also spelt as Oudh in British records), citing a deterioration in law and order. ${ }^{39}$ Juan Cole points out that these conflicts involve a complex patchwork of authorities, including the Shia king of Awadh, the Shia ulema, the British government, and their attempts to regulate the relationships between Hindus, Sunnis, and Shias in the region. ${ }^{40}$

The roots of the conflict can be traced to a dispute in 1855 , when Sunni Muslim protesters became convinced that the Hanumangarhi temple, dedicated to Hanuman, a Hindu deity, had been built atop the site of an old mosque, and they determined to tear it down and restore the mosque. This became serious enough, in February of 1855, to be noticed by Maj.-Gen. Outram, Calcutta's Resident in Lucknow, who wrote to the king Vajid 'Ali Shah, asking him to arrest a Sunni Muslim in Faizabad, by the name of Shah Ghulam Husayn, and a militant cleric supporting him, known as "Mawlavi Sahib." ${ }^{\text {"1 }}$ In 1855, 500 Muslims clashed at Ayodhya with some 8,00o Hindus (many of them ascetics known as Bairagis), leading to a massacre of the outnumbered Muslims. Angered by this event, Sunni Muslims pressurized the king to constitute a commission of inquiry, which came to the conclusion that no mosque had ever existed on the site of Hanumangarhi. This led to further clashes between the Sunni Muslims and Hindus, the Sunni Muslims being infuriated by the Shia king's inability to take action on the issue. The British Resident's pressure on the monarch not to

38 For a description of the regulation of places of worship in the princely state of Mysore, and an account of the development of the place of worship in the context of its legal history, see Geetanjali Srikantan, "The Difficulties of Religious Pluralism in India: Analysing the Place of Worship as a Legal Category in the Ayodhya and Bababudangiri Disputes", ARI Working Paper No. 187 (2012).

39 Sushil Srivatsava, "How the British saw the Issue", in Gopal Sarvepalli (ed.), Anatomy of a Confrontation. The Babri Masjid Ramjanmabhoomi issue (Penguin Books, 1991), 38-57. A colonial history is provided in A.G Noorani, The Babri Masjid Question 1528-2003, Volumes 1 and 2 (Tulika Books, 2004).

$40 \quad$ Supra n. 3 .

41 Ibid. A description of the dispute is provided at $244-249$. 
act against the Hindus further complicated the matter, leading to riots by the Sunni Muslims, which were quelled by the army of the Shia king. ${ }^{42}$

An entirely different account of this dispute entered judicial discourse in 1885, when one of the holy men, called the Mahant Raghubar Das, filed a suit for permission to construct a temple at the chabutra (a raised platform), claiming that he could do so because he owned and possessed the land on which the chabutra was built. The event that became judicial facts was that a riot occurred in 1855 at a nearby temple, called Hanumangarhi, following claims by Muslims that it had previously been a mosque. The riot started at Hanuman Garhi, where the Muslims were repelled by the Hindus. Several Muslims died and were buried around the disputed area. A railing was built dividing the land in such a way that Muslims used the inner courtyard near the Masjid, and the Hindus the outer courtyard. The Mahant pleaded that a temple be constructed over the chabutra, as the climate conditions (rain, sun, and extreme cold) often caused hardship for pilgrims and for the Bairagis themselves. The court noted that the chabutra was in the possession of Hindus whose "ownership could not be questioned, and around it there is the wall of the mosque and the word Allah is inscribed on it."43 This claim was rejected by the court on the ground that: ${ }^{44}$

If a temple is constructed on the Chabutra at such a place then there will be the sound of bells of the temple and shankh when both Hindus and Muslims pass from the same way, and if permission is given to Hindus for constructing temple then one day or the other a criminal case will be started and thousands of people will be killed... awarding permission to construct the temple at this juncture is to lay the foundation of riot and murder, hence between Hindus and Muslims, which are two different religions, in view of justice the reliefs claimed should not be granted.

The case then went to the District Judge of the Faizabad court, who agreed with the decision of the lower court and dismissed the appeal, although noting specifically that the chabutra indicated the birthplace of Ram, the Hindu deity.

42 See also the chapter "Sacred Space and Holy War: The Issue of Jihad", in Juan Cole, Sacred Space and Holy War: The Politics, Culture and History of Shi'ite Islam (I.B. Tauris, 2002), 161-172, upon which the abovementioned description is based.

43 For a narration of these facts, see Sub Judge Hari Kishan, Faizabad, in a Judgment dated December 24, 1885, quoted in Noorani, Volume 1 (note 39).

$44 \quad$ Ibid., 181. 
The Mahant then appealed to the highest court in the province. The Judicial Commissioner noted that: 45

...the Hindus of Ajodhya want to create a new temple ... over... the birthplace of Shri Ram Chandar. Now this spot is situated within the precinct of the grounds surrounding a mosque erected some 350 years ago owing to the bigotry and tyranny of the Emperor Babur, who purposely chose this holy spot according to Hindu legend as the site of his mosque.

The Judicial Commissioner supported the decisions of the lower courts and also noted that the Hindus have constantly been trying to expand their rights. He also dismissed the appeal on the ground that the plaintiff was not in any sense the proprietor of the land in question.

These three 19th century decisions by colonial courts are significant for the manner in which they establish certain facts without enquiry or proof. These facts are that the birthplace of Ram lies within the precincts of the mosque and that the mosque was built by the Mughal ruler Babur to humiliate the conquered Hindus. The decision by the Judicial Commissioner also added two other dimensions to these facts. It understood the Mahant's claim to "ownership" as title within the framework of modern property law, and it converted the Mahant's ownership claim from an individual claim on behalf of his community into a property claim on behalf of a "religion," i.e., the "Hindus."

\section{$2.2 \quad 20 t h$ Century Shifts and the Transformation of the Dispute}

Establishing these facts as some form of legal truth influenced the manner in which the dispute developed in the 2oth century. After 1886, the first event of consequence occurred in 1934, when riots were triggered by cow slaughter, and the Babri Masjid was damaged and rebuilt. ${ }^{46}$ An inquiry was conducted in 1936 by the Commissioner of Waqfs over a disputed land, to determine whether it was wakf. The Commissioner determined that the Babri Masjid was built by Babur, who was a Sunni Muslim..$^{47}$ This report provided the juridical basis for the property, showing that it fulfilled the requirements for the property to be considered wakf, i.e., it had been built by Babur. The Commissioner appointed

45 See the Judgment of W. Young, Officiating Judicial Commissioner, Oudh, dated 1 November 1886, quoted in Noorani, Volume 1 (note 39), 187-188.

46 See Parmanand Singh, "Legal History of the Ayodhya Litigation", 17(2) Indian Bar Review (1991), 31, quoted in Noorani (note 39).

47 Report of Faizabad District Wakf Commissioner, February 8, 1941, quoted in Noorani, Volume 1 (note 39). 
Syed Abdul Baqi as the mutavalli (the manager of the wakf). Such a wakf was legitimized by grants from previous Muslim rulers, which the British colonizers had continued. The ruling also reconciled sectarian differences by stating that even if the mutavalli was Shia, the wakf remained a Sunni wakf because the founder was the Emperor Babur, who was a Sunni Muslim. This report was adduced in the 1945 litigation between the Shia Central Board of Waqfs and the Sunni Central Board of Waqfs in the court of the civil judge in Faizabad.48 The report of the Commissioner had left unanswered the question of the sect that Abdul Baqi belonged to, but the judgment of 1945 further reconciled sectarian differences by asserting that Baqi was a Persian, and therefore a Shia, but the wakf was Sunni because it was founded by Babur a Sunni Muslim. This assertion was based, among other evidence, on reliance on a colonial digest by Bailee, stating that all Persians were Shia after 1499.

Such a declaration of wakf was possible only in the 2oth century, when a plethora of wakf legislation was enacted governing the different regions in the British Empire, such as the Bihar and Orissa Mussalman Wakf Act, 1926, the Bengal Wakf Act, 1934, the Bombay Mussalman Wakf Act, 1935, and the United Provinces Muslim Wakf Act, 1936, establishing the legal category of wakf. ${ }^{49}$ The lack of developments between 1886 and 1934 lend credence to this view.

The declaration that the mosque is "property" plays the crucial role in understanding the key moment in the dispute, which occurred on the night of the 22nd/23rd of December, 1949 when idols were placed under the central dome of the mosque by Ram devotees. This event laid the foundation for the Hindu claim to the property through the presence of the idol and the events that followed. On the 29th of December, the property was attached and placed under receivership. The scheme by the receiver specified the maintenance of bhog (offerings) and puja (worship), and the number of pujaris (priests). ${ }^{50}$ This allowed the worship of the idols without hindrance. The first suit was filed in 1950 by a Hindu devotee, Gopal Visharad, claiming that he be allowed worship of the idols without any hindrance. In 1959 another suit was filed by the Nirmohi Akhara, the order of the ascetics that had occupied the chabutra. The

48 Judgment of S.A. Ahsan, Civil Judge, Faizabad dated March 30, 1946, quoted in Noorani, Volume 1 (note 39).

49 This is not to argue that the wakf as an institution only came into existence during the colonial period. It has existed in the Islamic world for a long period, and was brought into India with the advent of Islamic rule. But the legal institution that underlay this form of regulation was different from the modern legal framework that takes the form of trusts, wakfs, and Hindu endowments, which was created by the British.

The Receivers Scheme quoted in Noorani Volume 1 (note 39). 
Sunni Central Board of Wakfs filed a suit in 1961 seeking to restore the mosque to the Muslims. In 1986, the locks were opened to facilitate worship by the general public, and the dispute became national. This prompted another suit, filed in 1989 by representatives of the Vishwa Hindu Parishad (the World Council of Hindus) a Hindu organization claiming to represent the interests of all Hindus, as next friend of the two idols, Bhagwan Ram Lal Virajman and Asthan Ram Janam Bhumi, who they claimed were juristic entities.

It is relevant to note at this juncture that the law of Hindu endowments had already developed in tandem with the wakf law, and various enactments, such as the Mysore Religious and Charitable Institutions Act of 1927, and the Madras Hindu Religious Endowments Act of 1923 had been passed in different regions. Under the law of Hindu endowments in India, the Hindu deity is recognized as a juristic person who can sue and be sued. Because the deity, an inanimate object, cannot act for itself, it is represented by the shebait or manager who can sue on its behalf. A long list of rulings by colonial judges helped establish these principles quite clearly. One of the most important cases was Hanooman Persaud Pandey v. Mussumat Babooee Munraj Koonweree, ${ }^{51}$ which held that the duties of the shebait representing the idol are akin to those of the manager of an infant heir's estate. ${ }^{52}$ In Pramanatha Mullick v. Pradyumna Kumar Mullick, ${ }^{53}$ the court held that a Hindu idol is a juristic entity that can sue and be sued, and that the deity had to be treated as a living being. The conception of the idol as significant in making a property claim was therefore already available present in the legal consciousness. The action of placing the idol under the central dome of the mosque must thus be understood as making a property claim, one that crystallized only 40 years later.

Demands by various political parties and Hindu groups affiliated with the Ram temple, who mobilized people though various campaigns, such as rath yatras, ${ }^{54}$ finally led to the demolition of the mosque, on December 6, 1992. Subsequently, the Central Government of India acquired a large area of about 68 acres, including the premises in dispute, through Acquisition of Certain Area at Ayodhya Act, 1993 (the Acquisition Act). The President of India asked the Supreme Court, with reference to Article 143 of the Constitution of India, whether a Hindu temple or any Hindu religious structure existed before the

$51 \quad 18566$ M.I.A. 393 .

52 This was reiterated in Manohar Ganesh Tambekar v. Lakhmiram Govindram 188712 ILR Bom 247 and Maharanee Shibesouree Debia, Trustee and Guardian of Her Minor Son Koomar Gobindnadh Roy v. Mothooranath Acharjo 186913 M.I.A 270.

54 http://www.bjp.org/leadership/shri-lk-advani/yatras/?u=ram-rath-yatra. 
construction of the Ram Janam Bhoomi and Babri Masjid (including the premises of the inner and outer courtyards on such structure).

The Supreme Court refused to answer the reference..$^{55}$ It struck down Section 4(3) of the Acquisition Act, which had directed abatement of all pending suits, as unconstitutional and invalid, and upheld the validity of the remaining Act. The result of this decision was that the four suits were revived and decided in the landmark judgment of September 30, 2010.

The developments in the latter half of the 2oth century are characterized by attempts of various parties to the suits to assert property claims on the site. But although these claims are couched in the language of secular law, they also articulate religious rights. The Supreme Court decision reflects the tension between protecting religious freedom and guaranteeing property rights.

How are such religious rights enforced as claims to property is evident in a statement from the judgment: ${ }^{56}$

A temple, church or mosque etc. are essentially immovable properties and subject to protection under Articles 25 and 26. Every immovable property is liable to be acquired. Viewed in the proper perspective, a mosque does not enjoy any additional protection which is not available to religious places of worship of other religions.

Based on jurisprudence of Articles 25 and 26, the Court also held that "protection under Articles 25 and 26 of the Constitution is to religious practice which forms an essential and integral part of the religion." ${ }^{.57}$ Thus, a practice could be a religious practice but not an essential and integral part of the practice of the religion.

In interpreting this principle, the Court held, controversially, that a mosque is not an essential part of the practice of Islam, and that namaz or prayers by Muslims can be offered anywhere, even in the open. It also held that title to a mosque can be lost by adverse possession, quoting the colonial precedent of Masjid Shahid Ganj and Ors. v. Shiromani Gurdwara Prabandhak Committee, Amritsar. ${ }^{58}$ The right of acquisition of a religious place must be made only in extraordinary situations, with a larger national purpose in mind, and should not result in the extinction of the religious right.

55 Ismail Farooqui v. Union of India AIR 1995 SC 605.

$56 \quad$ Ibid., Para 85.

57 Ibid., Para 81. The Court here relies on the essential practices test laid down in the Shirur Mutt case (note 23), which, however, is not explicitly mentioned.

58 AIR 1938 Lahore 369. 
The Court drew further on colonial case law by commenting that in British India, the right of Muslims to worship in a mosque and of Hindus in a temple had always been recognized as a civil right. It further remarked that before 1950, the year in which the Indian Constitution came into force, the Indian Courts in British India had maintained the balance between the different communities or sects in respect of their right of worship. Therefore, the tension between religious rights and claims to property was understood as a matter of equal treatment of religions.

It is apparent that the various shifts in the dispute have allowed certain questions to become predominant. In the 19th century the dispute could be characterized as a local conflict between different interest groups, which was transformed into a property dispute between two communities: Hindus and Muslims. Such a dispute was further defined as being over religious rights to property by using the categories of the wakf and of the Hindu endowment. In the latter half of the 2oth century, the dispute was over the equal treatment of religions. These shifts formed the backdrop of the issues and questions that were framed and answered by the Allahabad High Court in the Ayodhya judgment.

The key questions in this judgment were (a) is the site of the demolished mosque the birthplace of Lord Ram? (b) Is the suit a representative one, with the two parties to the dispute representing the interests of all Muslims and Hindus respectively? (c) What are the rights of adverse possession with respect to both Hindus and Muslims at the site? d) How long have the idols on the site been in existence? (e) Is the building a mosque? (f) Has it been constructed on the site of an alleged Hindu temple? (g) Is the building dedicated to Almighty God? (h) Has it been used for prayers by Muslims since time immemorial?

The judgment was delivered by a three-member bench that included Justice Sibhghat Ullah Khan (the sole Muslim judge), Justice Sudhir Agarwal, and Justice Dharam Veer Sharma. ${ }^{59}$ The judges Khan and Agarwal delivered the majority opinion, with Judge Sharma dissenting.

The majority opinion divided the disputed land into three equal parts. The area covered by the central dome of the mosque being the place of birth of the Hindu deity, Ram, and being occupied by the idol Bhagwan Ram, called

59 A brief background of the judges is provided at http://www.ndtv.com/india-news/ayodhya -verdict-the-judges-who-delivered-todays-verdict-433810. Both Justice Khan and Justice Agarwal delivered single judgments, answering the issues in all the suits, Justice Agarwal's judgment running into 21 volumes. Justice Sharma, however, addressed the suits separately, delivering separate judgments (the suit numbers are cited when quoting from his judgments). 
the Janamsthan, was declared as belonging to the idols as juristic persons. The area at the outer courtyard of the mosque, including the chabutra and another structure known as the Sita Rasoi, was granted to the Nirmohi Akhara. The Muslim parties (the Sunni Wakf board) and other individual litigants were awarded one third of the land, with a direction that the government award parts of the land that have been acquired under the Ayodhya Act to make up for the deficit. The dissenting judgment, by Judge Sharma, however, was in favor of the land going to the idols as juristic persons. The Nirmohi Akhara refused to accept the decision, claiming rights to the area where the idols were placed, covered by the central dome of the mosque. The present status of the litigation is that the parties have appealed to the Supreme Court.

\section{3 \\ Judging Competing Claims: The History of "Hindu Religion" vis-à-vis Islamic Juridical Title to Property}

\subsection{Colonial Discourse and the Birthplace of Ram}

The long and complex litigation involving the Ayodhya dispute resulted in a voluminous, 8,00o-page judgment on September 30, 2010. The judgment examined repetitively the evidence of witnesses, which included archaeologists, historians, members of the local community (both Hindus and Muslims), representatives of the Sunni Wakf Board and of the Vishwa Hindu Parishad among others. It also studied in detail the various legal doctrines used in the judgment, such as adverse possession and limitation.

The judgment has been highly criticized for inadequate legal argumentation and analysis with respect to the property rights of Muslims and its interpretation of the law of limitation. It has also been criticized for being an unworkable decision, each of the judges showing inconsistencies in reasoning with respect to relief. Justice Khan found joint possession between Hindus and Muslims but divided the property into three parts for three different parties: the idols, Nirmohi Akhara, and the Muslim community represented by the Sunni Wakf Board. Justice Agarwal found that both Hindu and Muslim parties had possession of the inner courtyard, but held that the area under the central dome should be included in the share of the idols as juristic entities. The open area in the outer courtyard was to go to the Nirmohi Akhara and the idols, but the constructed area, in the form of the chabutra, and another area known as Sita rasoi, was to go to the Nirmohi Akhara. Justice Sharma granted the deities the entire property. The verdict has been criticized for its inability to correctly 
assess historical and archaeological evidence, ${ }^{60}$ and for using questionable historical evidence to arrive at a new doctrine of a place of worship, where a birthplace is considered as a deity. ${ }^{61}$

It is obvious that such a decision is the result of the attempt to answer the questions and issues that have been framed. These questions cannot be asked and answered without the assumption that Ayodhya was a place of significance for the Hindus. As we have seen in the 19th century judgments, such an assumption appeared to require no proof or evidence. What was the reason for this? In the judgment of September 30, 2010, all three judges relied greatly on the gazetteers that recorded the statements of European travelers, colonial administrators, etc. to establish that a mosque had been built by Babur (adduced by the Muslim parties), and that the temple of the Hindu deity Ram was demolished by him. All the judges accepted the fact that the gazetteers formed the basis for legal truth in different ways. Justice Sharma argued that it must establish facts of which courts can take judicial notice, ${ }^{62}$ Justice Agarwal commented that the gazetteers carried an account of true historical facts, ${ }^{63}$ whereas Justice Khan used the gazetteers to comment on historical and legal facts. ${ }^{64}$

These stories begin with William Finch, who in 1608-1611 commented in his travel account as follows: ${ }^{5}$

To Oudh [Ajodhya] from thence are 5oc; a citie of ancient note, and seate of a Potan king, now much ruined; the castle built foure hundred yeeres agoe. Heere are also the ruines of Ranichand ${ }^{66}[\mathrm{~s}]$ castle and houses, which the Indians acknowled[g]e for the great God, saying that he tooke flesh upon him to see the tamasha ${ }^{67}$ of the World. In these ruines remayne certaine Bramenes, who record the names of all such Indians as wash themselves in the river running thereby; which custome, they say, hath continued foure lackes of yeeres (which is three hundred ninetie foure thousand five hundred yeeres before the worlds creation).

\footnotetext{
6o See Menon, n. 21.

61 See Gautam Patel, "Idols in Law", 45(50) Economic and Political Weekly (2010), 47-52.

62 Justice Sharma, Vol. 2 (o.s 4 of 1989), p. 299.

63 Justice Agarwal, Vol. 7, p. 1561.

64 Justice Khan, p. 221.

65 William Foster (ed.), Early Travels in India (Oxford University Press, 1921), 176.

66 Ibid. Rama Chandra, the hero of the Ramayana. The reference is to the mound known as the Ramkot or fort of Rama (reproducing the footnote on p. 176).

67 Ibid. Hind. tamasha, a show or spectacle (reproduced in the footnote on p. 176).
} 
The next account of interest is that of Joseph Tiefenthaler, from 1770, which talks about several temples dedicated to Ram, and a heavenly temple where Ram carried people to heaven. He also mentions that: 68

The emperor Aurangzebe demolished the fortress called Ramcote, and erected on the site, a Mohammedan temple with a triple dome. According to others, it was erected by Baber. There are to be seen fourteen columns of black stone, five spans in height, which occupied the site of the fortress....

On the left is seen a square chest raised, five inches from the ground covered with lime, about 5 ells in length by not more than four in breadth. The Hindoos call it Bedi, the cradle; and the reason is, that there formerly stood here the house in which Beshan (Vishnoo) was born in the form of Ram....

Tiefenthaler ends this account by noting that Aurangzeb or Babur had caused this place to be destroyed, so that "the heathen could not practice his superstitions," but the place is still frequented by people who show reverence by going around this place three times and by prostrating themselves on the earth.

In 1828 , another gazetteer by Walter Hamilton, mentioned the ruins of the city, and that inland a mass of rubbish and jungle lay among, which are the reputed sites of temples. ${ }^{69}$ Yet another travel account, by Francis Buchanan (compiled by Montgomery Martin), spoke of temple destruction, attributing it to Aurangzeb, but adding that the mosque appears to be quite modern and has an inscription on its walls indicating that it had been built by Babur. He wrote that heaps of bricks have been carried away to build the Muhammadan Ayodhya. In digging for bricks, images have been found but they are far too broken to know what they represent. He commented that some pillars in the mosques built by Babur were made of black stone: ${ }^{70}$

That they have been taken from a Hindu building, is evident, from the traces of images being observable on some of their bases; although the images have been cut off to satisfy the conscience of the begot.

68 This extract, which is mentioned as being Annexure IV, "Description of India" by J. Tiefenthaler, 129-162, is taken from Justice Sharma Vol. 2 (o.s. 4 of 1989), p. 55.

69 Ibid., 57.

$70 \quad$ Justice Agarwal Volume 7, p. 1718. 
This reference to the mosque is repeated in Edward Thorton's gazetteer of $188^{8},{ }^{71}$ which say that Aurangzeb's demolition of the mosque shows the falsehood of the tradition because of the inscription referencing Babur. Like Tiefenthaler, he observes the cradle of Ram, using the exact language of 5 ells long, etc. and the mosque being embellished with 14 columns taken from the ruins. He further cites other observations of Buchanan to the effect that heaps of bricks in the city attested to the ruins of an ancient and large structure, and that the mosque was built with materials taken from the ruins.

These observations become relevant because the archaeological evidence uncovered similar truths. Cunningham's Report of the Archeological Survey of India (A.S.I. 1862-1864) ${ }^{72}$ mentioned that there were several very holy temples in Ayodhya, some of them built on the sites of older temples that have been destroyed by the Muslims. The Babri Masjid was not, however, mentioned as being one of them.

Carnegy's historical sketch of Faizabad, from $1870,{ }^{73}$ turned these historical observations into historical truth. He remarked that Ayodhya is for the Hindus in the same way Mecca is for the Muslims and Jerusalem is for the Jews. He also mentioned specifically the place where Rama was born as being a particular temple known as the Janmasthan. He suggested that there must have been a temple at the Janmasthan because its columns had been used in the construction of the Babri Masjid. He added that the pillars of the Babri Masjid were of black stone and resembled Buddhist pillars. He also provided an account of the 1855 conflict.

The Gazetteer of Oudh, from $1877-1878,{ }^{74}$ describes Ayodhya as being:

...to the Hindu what Mecca is to the Mohammadans, Jerusalem to the Jews; it has in the traditions of the orthodox, a highly mythical origin, being founded for additional security, not on the transitory earth, but on the chariot wheel of the Great Creator himself.

An archeological survey report of 1889 corroborated these events by specifically mentioning the inscriptions on the mosque and the fact that the mosque

71 See the entry on "Oude" in Edward Thornton, A Gazetteer of the Territories under the Government of the East India Company and of the Native States on the Continent of India (W.H. Allen, 1858).

72 Alexander Cunningham, Archaeological Survey of India: Four Reports Made During the Years 1862-63-64-65 (Government Central Press, 1871), 322.

73 For a discussion of these points, see Justice Khan, 218-221.

74 Judge Sharma, Vol. 2 os 4 of 1989, p. 63. 
was on the spot of the Ram temple known as Janmasthan. ${ }^{75}$ In 1905, the Fyzabad Gazetteer by Neville ${ }^{76}$ commented that Babur built a mosque at the birthplace of Rama in 1528 . The Imperial Gazetteer of $1908^{77}$ further identified Rama's birthplace, adding that it is occupied by the mosque.

The Fyzabad Gazetteer of 1928 repeated the contents of the earlier gazetteers: ${ }^{78}$

It is locally affirmed that at the time of the Musalman conquest there were three important Hindu shrines at Ajodhya and little else. These were the Janamasthan temple, the Swargaddwar and the Treta-ka-Thakur, and each was successively made the object of attention of different Musalman rulers. The Janamasthan was in Ramkot and marked the birthplace of Rama. In 1528 A.D. Babar came to Ajodhya and halted here for a week. He destroyed the ancient temple and on its site built a mosque, still known as Babar's mosque. The materials of the old structure were largely employed, and many of the columns are in good preservation...

\subsection{Between the Invader and the Colonizer: Locating Sovereignty in Religion and Property}

The gazetteers describe a conflict in which a temple has been demolished by a medieval Mughal emperor, and a mosque built on its ruins. A crucial point is that there is complete silence on this matter before the gazetteers. The courts themselves noted that there is no mention of such an incident in Babur's memoirs. There is also no mention of it in Mughal histories. ${ }^{79}$ In this conflict, the two claims in the legal domain are made by two communities with different forms of evidence: a property claim and a historico-theological claim. These claims manifested themselves in the use of the categories of the wakf and of the endowment, and were based on secular law.

The claim by the representatives of the Muslim community, which is based on a notion of title, states that Babur conquered Ayodhya in 1528 and dedicated the mosque to the Almighty. This brought about a property rights claim, with the Muslim community adducing evidence of possession since 1528 . The claim led to a counter-claim by representatives of the Hindus, who argued that

75 Justice Agarwal Volume 7, p. 1584.

76 Justice Agarwal Volume 7, p. 1572.

77 Ibid., p. 1573.

78 Ibid., pp. 1581-1582.

79 Justice Agarwal Vol. 14, p. 3442. 
one cannot have possession against the deity. They adduced archaeological evidence showing that there had been a temple prior to the building of the Babri Masjid, with the deity resident therein, and that the deity Ram had always "existed" on the basis of the faith and belief expressed in poetry and stories around the deity, such as the Ramcharitmanas and the Ayodhya Mahamatya.

To determine the religious rights of the parties, which had the effect of also determining their rights to property, the Court was forced to identify the sovereign legal order upon which such property rights could be based and religious rights granted. The lawyers representing the Hindu community argued that King Babur had acquired sovereignty over Delhi, Agra, and Oudh, defeating Sultan Ibrahim Lodi in the battle of Panipat. ${ }^{80}$ These territories were constituent of "Dar-ul-Islam" (land under Islamic law) because Ibhrahim Lodi was a Muslim and followed the Sharia. Therefore, Babur acquired only those territories that he could have under the Sharia, and not the land owned by his Hindu subjects and their endowments. These contentions cast Babur as an invader and not an emperor. All three judges examining this claim were influenced by secular property law in their conclusions.

In response to this contention, Justice Agarwal argued that it is not possible to say that sovereignty did not rest in Babur. But even if Babur was owner, there was no evidence that the wakf had been validly dedicated. ${ }^{81}$ This was apparent in the inscriptions on the mosque, adduced as evidence of the dedication being unreliable (they had been damaged in the 1934 riot).$^{82}$ There was also no evidence in the gazetteers of exclusive possession by Muslims, ${ }^{83}$ and of the fact that Islam does not allow two religions to use the same place of worship. ${ }^{84}$ Unlike Islam, there are no similar prohibitions in the Hindu Dharmasastras. ${ }^{85}$

To reach these conclusions about sovereignty, Justice Agarwal used the modern legal concepts of evidence, customary use, and possession to judge the claim of the Muslim community regarding its title to property. He also reached the conclusion that Babur did not demolish the temple, but argued, that the temple had been demolished based on the archaeological evidence. The archaeological evidence is interpreted based on the assumption that the Hindus considered the site to have religious significance. This once again brings into operation secular property law, as Justice Agarwal relied on colonial travel

\footnotetext{
8 o Justice Agarwal, Vol. 14, p. 326o.

81 Justice Agarwal, Vol. 14, pp. 3288-3289.

82 Justice Agarwal, Vol. 14, pp. 3336-3337.

83 Justice Agarwal, Vol. 8, p. 1767.

84 Ibid.

85 Justice Agarwal, Vol. 14, p. 3341.
} 
narratives as eyewitness accounts corroborating ownership and possession by the Hindus. He noted that travel accounts did not mention worship by the Muslims, ${ }^{86}$ "the building in dispute was constructed but immediately thereafter or after sometime it stood deserted by Muslims," 87 and that Hindus found a way to continue worshiping at the site.

A similar approach was followed by Justice Khan, who also resorted to concepts of secular property law. If Babur demolished the temple, Justice Khan asked why this was not recorded in the Ramcharitmanas, a 16th century work eulogizing Ram. ${ }^{88}$ He argued, however, that the gazetteers mention a mosque, and therefore the identity of the disputed place should not be in dispute. ${ }^{89} \mathrm{He}$ acknowledged that Hindus were also using the place, and therefore Hindus and Muslims have joint possession. ${ }^{90} \mathrm{He}$ argued that it was not necessary to consider the archaeological evidence. ${ }^{91}$

Justice Sharma took a different approach and argued that the disputed Babri Masjid structure is not a mosque. This marks a radical departure from the position of the others, as it rejects modern property law as a primary mode of analysis, but does not reject the characterization of the dispute as being about title or ownership. Instead, the main mode of analysis becomes history and theology, which are used to make a "title" claim on behalf of the Hindus. His position on several issues differed from that of the other two judges, but was still based on the gazetteers.

Sharma rejected the property rights claim of the Muslims by arguing that the revenue grant by the British cannot constitute proof of title. ${ }^{92} \mathrm{He}$ also concluded that Babur had demolished the temple but had not acquired title because the acquisition was without the consent of the owner. By this action, Babur violated the tenets of the Quran, which mandates the consent of the owner before taking over property, and which he was obligated to follow as a Hanafi Muslim emperor. ${ }^{93} \mathrm{He}$ advocated the use of a historical and theological approach, by arguing that the mosque is the birthplace of Ram and deserves

86 Supra n. 83 .

87 Ibid.

88 Justice Khan, pp. 237-238.

89 If the structure on the disputed premises was not a mosque, there was absolutely no occasion, reason, or explanation why idols were not there before 23.12.1949. See Justice Khan, pp. $225^{-226 .}$

$90 \quad$ Justice Khan, p. 282.

91 Justice Khan, pp. 276-277.

92 Justice Sharma, Vol. 1 o.s. No.4/1989, p. 191. This is on the ground that it was a service grant to the grantees for collaboration with the British colonial regime.

93 Justice Sharma, Vol. 1 o.s. No.4/1989, pp. 112-113. 
the protection of Article 25 of the Constitution, which is the constitutional right of freedom of religion by being an essential practice of the Hindus: $\mathrm{He}$ argues that ${ }^{94}$

...the Asthan, Ram Janambhumi has been an object of worship as a deity by the devotees of Lord Ram as it personifies the spirit of divine worshipped in the form of Ram Lala or Lord Ram, the child. Ram Janmbhumi is also a deity and a juridical person. It is established from evidence that the Hindus worship the divine place in the form of God. The Hindus can mediate upon the formless and shapeless divine. The spirit of Divine is indestructible. Birth place is sacred place for Hindus and Lord Ram, who is said to be incarnation of God, was born at this place. The Hindus since times immemorial and for many generations constantly hold in great esteem and reverence the Ram Janambhumi where they believe that Lord Ram was born.

Justice Sharma relied on the gazetteers, classical literature, and oral evidence to establish that a temple existed on the premises. ${ }^{95} \mathrm{He}$ also relied on archaeological evidence, which bore a striking resemblance with the descriptions of gazetteers, showing that there was a temple. This included evidence such as an inscription of a Vishnu Hari temple, images of Hindu gods on pillars, and various kinds of stones that he insisted were from the temple. He argued that the structure was not a mosque because it did not have a minaret, idolatrous images were present on its pillars, there were no facilities for wazu or ritual washing, and it was situated in the midst of Hindu temples that sounded bells (a practice that is contrary to Islam). ${ }^{96}$

The nature of the normative inferences of this claim produced the most controversial aspect of the decision: the doctrine that the birthplace of a deity was also a juristic entity. Even more controversially, both Justice Sharma and Justice Agarwal argued that the deity was present in the disputed area since time immemorial. This allowed the two justices to reject the argument

94 Justice Sharma, Vol. 4 O.s. No.4/1989, pp. 181-182.

95 This finding was also supported by Justice Agarwal, who argued that the long and continuous belief of the Hindus, as the enormous amount of oral evidence, was sufficient to consider the place as deity. Justice Agarwal, Vol. 2o, p. 4997.

96 This was, however, refuted by Justice Khan, who held that it could not be used as a criterion to determine what a mosque is. See Justice Khan, pp. $255^{-258}$. All three judges rejected the property claim by the Muslims based on the fact that inscriptions in a mosque were valid. 
of the Muslim community that even if the deity was resident in the disputed area, they have obtained adverse possession since $15^{28}$. The judges argued that one cannot gain adverse possession against a deity who is a perpetual minor and had always existed on the property. This position was, however, refuted by Justice Khan, who quoted several judgments to show that the deity was not a perpetual minor in law.

Further questions arise regarding the judicial understanding of the Hindu endowment that enabled the judges to formulate such a doctrine. Why is there a legal debate on the status of the idol as a minor and a plethora of case law on the same? ${ }^{97}$ Why is the deity seen as an entity from which possession cannot be claimed? Why were claims on the issue of dedication or consecration of the idols not taken into account? Why are religious rights entangled within property law? Such questions can be answered only within the framework of the colonial origins of the dispute and its interaction with secular property law, which makes it possible to frame this dispute as one between two religions, and consequently apply the principle of equal treatment.

\subsection{Determining Religion: The Theological Elements of Modern Property Law and Colonial Discourse}

A characteristic feature of the judgment was its recognition of the birthplace of Ram as an essential part of the Hindu religion and of the core of Hindu faith, under Article 25 of the Indian Constitution. This is most apparent in Justice Sharma's decision: ${ }^{98}$

Lord Ram as the avatar of Vishnu having been born at Ayodhya at the Janmasthan is admittedly the core part of Hindu belief and faith which is in existence and practiced for the last thousands of years. The Hindu scriptures also sanctify it. Article 25 of the Constitution being a fundamental right ensures its preservation and no relief can be taken by the court which seeks to restrict or altogether extinguish this right.

Justice Agarwal argued similarly when speaking about the Hindu belief in Ram: 99

The case of Pramanatha Mullick v. Pradyumna Kumar Mullick has already been discussed. Other relevant cases concerning the role of the shebait, and comparisons between a minor and an idol are Prosunno Kumari Debya and Another v. Golab Chand Baboo 18752 I.A. 145, and Tarit Bhushan Rai v. Sree Iswar Sridhar Salgramsila Thakur, AIR 1942 Cal 99.

98 Justice Sharma, Vol. 4, o.s. No.4/1989, p. 121.

99 Justice Agarwal, Vol. 20, p. 4997. 
... once such belief gets concentrated to a particular point, and in totality of the facts, we also find no reason otherwise, it partakes the nature of an essential part of religion particularly when it relates to a matter which is of peculiar significance to a religion. It, therefore, stands on a different footing. Such an essential part of religion is constitutionally protected under Article 25.

These inferences are not surprising, as they appear to be drawn from the Supreme Court decision on what could be the essential practices of a religion (not all religious practices being essential practices). This raises the question of how religion itself is conceptualized (we noted above that it has been impossible to define religion in law). It appears from the judgment, however, that there is a certain conception of religion, derivedfrom colonial discourse, that influences property law. It is apparent from the various colonial gazetteers that the colonizers had a certain conception of a religion called "Hinduism," which was "superstitious" and therefore easily succumbing to an Islamic invader. This conception was restricted by the British colonizers' cognitive background, which recognized religion only within the framework of the Semitic religions' prohibitions against idolatry.

In his analysis of the nature of the Jerusalem Temple, Harold Turner showed how the character of the space of the temple represented a radical break with the religious traditions of that time. ${ }^{100}$ Such a break was due to the space no longer being considered magical in nature and available to human initiative, but "identified with the deity whose power is now inherent in it," that is, controlling the temple also controls its powers. In the context of the Jerusalem temple, such space becomes symbolic of the covenant between the people of Israel and their God. This transformation of space was adopted by Christianity with a difference, namely that Christ became the center of power and meaning, opening up communication between men and God in a new way. ${ }^{101}$

This understanding of space necessitated turning spaces for the practices of other traditions and the beliefs of others into places of worship of false gods. Halbertal and Margalit argued that the Semitic religions perceive that pagans as committing an error by worshipping idols, the error being that the idol is taken as the representation of God, thus transforming false worship into false

\footnotetext{
100 Harold Turner, From Temple to Meeting House: The Phenomenology and Theology of Places of Worship (Moulton Publishers, 1979), 83.

101 Ibid., 138.
} 
belief. ${ }^{102}$ This false belief is seen as part of a transition, the pagan's initial belief in God being reoriented toward building temples housing idols as representatives of God by the advice of false prophets. ${ }^{103}$

S.N. Balagangadhara shed further light on the question of worship, arguing that being religious involves seeing oneself as part of God's purposes. ${ }^{104} \mathrm{Be}-$ cause there is a link between the Will of God and the cause of the universe, worship is integral to the believer maintaining faith in such an account. Worship shows adherence to the exclusive domain of God. Halbertal and Margalit elaborated on the nature of this exclusive domain, arguing that: ${ }^{105}$

The ban on idolatry is an attempt to dictate exclusivity, to map the unique territory of the one God. The primary context is worship: worship must be exclusive to one force, sacrifices may be made only to God, and no one but him may be worshipped.

Such conceptions, derived from the Semitic religions, of religion and ideas of worship in Indian traditions, were not limited to the sources found in the gazetteers, and they form a body of discourse about an inferior Hindu religion characterized by its fall into idolatry. ${ }^{106}$ This attitude has infiltrated the legal ideas prevalent in the law of Hindu endowments as normative inferences. The idol is seen as "another god," which explains the doctrine of the idol being a juristic entity (it is necessary to show that it is the center that controls the powers of the temple). It also explains other requirements to be proved in law, such as dedication and consecration with respect to the idol. The concept of dedication is crucial to the idol because it acknowledges the idol's "sovereignty" as God. But the idol is not the creator of the universe and cannot claim an exclusive domain, therefore the colonial normative inferences that have infiltrated the Indian legal system cause a dissonance. ${ }^{107}$ These inferences include a representative to act for the idol in the form of the shebait (manager) or other worshippers. Although such representatives are supposed to perform

\footnotetext{
102 Moshe Halbertal and Avishai Margalit, Idolatry (Naomi Goldblum, trans.), (Harvard University Press, 1992).

103 Ibid.

104 See Balagangadhara, n. 31.

105 Supra n. 102, 5 .

106 See Geoffery Oddie, Imagined Hinduism: British Protestant Missionary Constructions of Hinduism, 1793-19oo (Sage Publications, 2006). See also Richard King, n. 31.

107 For more details on the conditions that underlie the legal category of the place of worship that includes dedication, God's authority, and the public and the private, see Srikantan, n. 38 .
} 
the function of a trustee, in practice they do the opposite and do not act for the idol but "act" as the idol. The idol cannot have purposes in the manner in which the God of Abrahamic religions has purposes for mankind. Moreover, worship of the idol also cannot be seen as understanding or adhering to its "will."108 Therefore, the manager exercises control over the properties vested in the idol in the way he deems fit.

This dissonance becomes particularly jarring when a dispute arises and another property claim falls within the framework of the Semitic religions. This happens in the case of the wakf, where dedication to God must be absolute, with total divestment of human ownership. ${ }^{109}$ In the case of the Hindu idol, these terms pose a challenge, dedication being a form of ritual toward the idol, performed by humans. This does not have the same character as dedication in the case of the wakf, being less compatible with the concept of ownership and transfer in property law.

It is relevant to note that in this judgment, Justices Agarwal and Sharma dispensed with the question of dedication altogether, arguing for the special status of the birthplace. In doing so, they adopted a conception of religion that conforms with colonial perceptions recorded in the gazetteers and travel accounts. This is most visible in a statement by Justice Agarwal on the nature of faith and belief among the Hindus: ${ }^{110}$

The dispute of Al Aqsa in Jerusalem... treated to be the third most pious place by muslims since they believe that Prophet Muhammad descended thereat after visiting heaven, nobody even doubt their faith but one can always ask a question that Jerusalem is not mentioned in Quran at all while Mecca and Madina words have been used innumerably then what is the evidence for such belief but then one must understand and appreciate that in the matter of faith and religion such things cannot be asked. A religion itself means if some people believe something and worship as a matter of right, since the time immemorial, the others must not raise any doubt. Simple logic is that failing to find evidence to something does not necessarily result in that the thing does not exist.

In trying to make Ayodhya the "Jerusalem of the Hindus," the judges deployed not only the theological framework of the Semitic religions but also

108 Despite this incongruence, there are Indian court decisions such as the Pramanatha case (n. $5^{2}$ ) that speak of the will of the idol.

109 See Vidya Varuthi v. Balusami Ayyar 192148 I.A. 302.

110 Justice Agarwal, Vol. 19, p. 4551. 
the normative inferences that have seeped into property law. By defining worship as belonging to the exclusive domain of God as sovereign, they held that there can be no adverse possession against the deity. By reiterating that the birthplace of a deity was a juristic person, they sought to model the Indian traditions described as Hinduism according to the framework of the Semitic religions. This is manifest in Justice Sharma's argument that the "Nature of Hindu religion is monism. It believes in one supreme being, who manifests Himself in many form," ${ }^{111}$ and the existence of an idol, although desirable, is not a legal precondition for worship, as divinity can also be formless. ${ }^{112}$ Images are symbols of a Supreme God to whom all the functions of creation, preservation, and destruction are attributed. ${ }^{113}$

This approach causes further dissonance in the attempt of the Court to interpret archaeological evidence in its favor. Prominent archaeologists have criticized the handling of archaeological evidence by the Court on the ground that it did not meet the professional standards of archaeology as a discipline. ${ }^{114}$ In a commentary on the judgment, it has been argued that black stone pillars, a mutilated sculpture, and a stone slab with symbols cannot be understood as constituting a temple because they could have been introduced from anywhere. ${ }^{115}$ It is further argued that excavations do not show the presence of a "north Indian temple," which needs to have certain features, such as pillared porches.

Such criticism, as Tapati Guha-Thakurta has pointed out, ${ }^{116}$ does not question the epistemology within archaeology itself, that is, the manner by which it produces knowledge and converts objects into monuments. It also does not deal with the theological framework by which a temple is described in law. Within the framework provided by the justices, a temple could be practically any structure, provided evidence is adduced of "belief in its divinity."

\footnotetext{
111 Justice Sharma, o.s. No.5/1989, p. 173.

112 Justice Sharma, Vol. 4 O.s. 4 of 1989, p. 30.

113 Justice Sharma, Vol. 4 O.s. 4 of 1989, p. 32.

114 See Shereen Ratnagar, "Archeaology at the Heart of a Political Confrontation", 45(2) Current Anthropology (2004), 239-259. See also Ram Sharan Sharma, "The Ayodhya Issue" in Robert Layton, Peter G. Stone and Julian Thomas (eds.), Destruction and Conservation of Cultural Property (Routledge, 2001).

115 See Supriya Varma and Jaya Menon, "Was there a Temple Under the Babri Masjid: Reading the Archaeological Evidence", 45(50) Economic and Political Weekly (2010), 61-72.

116 See Tapati Guha-Thakurta "Archaeology as Evidence: Looking Back from the Ayodhya Debate", Occasional Working Paper No. 159 (Centre for the Study of Social Sciences, Calcutta, 1997).
} 
The Ayodhya litigation exposes difficulties in the application of the doctrine of secularism outside predominantly Christian and Western societies. The difficulty of the Indian state in applying the doctrine of secularism, that is, the inability of the state to be neutral and to treat religions in an equal manner, is extremely noticeable in the above analysis. The inability does not lie in the inadequacy of the application of the doctrine of secularism but in its consequences for the social phenomena to which it is applied.

In the case of the Ayodhya dispute, we have seen how colonialism introduced certain normative inferences about the nature of different communities and the relationships between them, leading to a local conflict being described as a religious one. The introduction of secular property law in determining the religious rights of Hindus and Muslims further exacerbated the conflict, as the courts found it difficult to apply the principle of equal treatment because the application of the wakf and the Hindu endowment has different results in property law. Concepts of ownership, transfer, and sovereignty lack cognitive value with respect to the Hindu endowment because of the status of the idol as a juristic entity. The courts are thus forced to rework legal categories to make religions "equal." This is apparent in the pronouncement that a deity has a birthplace, which attempts to emulate the model of a formless creator God in the Semitic religions, and in the process distorts Indian traditions and practices.

The application of the doctrine of equal treatment of religions in the Ayodhya dispute leads to more conflict and antagonism between communities because of these inadequate legal models and the normative inferences that have played a role in describing the dispute as religious. It is worthwhile to note that this dispute has its origins in colonial descriptions, and that many of the legal concepts and categories that have been used in the judgment also have their origins in colonialism. Reworking legal concepts and categories is inadvisable, unless the normative references replete in colonial discourse are unraveled. This includes not only concepts contained in secular property law and their application, but also the perspective that the relationships between communities are of religious antagonism, because these descriptions are enabled by the normative inferences introduced by colonialism.

These findings also shed light on the practical effects of the doctrine of secularism as practiced by the Indian state. They show that the concept of equal treatment between religions can be unworkable in the legal domain. This should make us rethink not only secularism but also the manner in which religious freedom, such as the right to worship, is articulated. This poses new challenges for understanding relationships between communities. 